\title{
Microbial pathways for the reduction of mercury in saturated subsurface sediments
}

\author{
Final report \\ Submitted by: \\ Tamar Barkay, Lily Young \& Gerben Zylstra (Rutgers University)
}

Mercury is a component of mixed wastes that have contaminated vast areas of the deep subsurface as a result of nuclear weapon and energy production. While this mercury is mostly bound to soil constituents episodes of groundwater contamination are known in some cases resulting in potable water super saturated with $\mathrm{Hg}(0)$. Microbial processes that reduce $\mathrm{Hg}(\mathrm{II})$ to the elemental form $\mathrm{Hg}(0)$ in the saturated subsurface sediments may contribute to this problem. When we started the project, only one microbial pathway for the reduction of $\mathrm{Hg}(\mathrm{II})$, the one mediated by the mer operon in mercury resistant bacteria was known. As we had previously demonstrated that the mer mediated process occurred in highly contaminated environments (Schaefer et al., 2004), and mercury concentrations in the subsurface were reported to be low (Krabbenhoft and Babiarz, 1992), we hypothesized that other microbial processes might be active in reducing $\mathrm{Hg}$ (II) to $\mathrm{Hg}(0)$ in saturated subsurface environments. The specific goals of our projects were:

1. Investigating the potential for $\mathrm{Hg}$ (II) reduction under varying electron accepting conditions in subsurface sediments and relating these potential to mer gene distribution.

2. Examining the physiological and biochemical characteristics of the interactions of anaerobic bacteria with mercury.

The results are briefly summarized below with references to published papers and manuscripts in preparation where details about our research can be found. Additional information may be found in copies of our published manuscripts and conference proceedings, and our yearly reports that were submitted through the RIMS system.

Hg(II) reduction under denitrifying and iron reducing conditions: We initially evaluated the toxicity of mercury to denitrifying Oak Ridge FRC sediment enrichments. We derived a nitrate reducing enrichment culture by incubating sediment from the background area in an artificial ground water medium (AGW) supplemented with $10 \mathrm{mM}$ acetate and $5 \mathrm{mM}$ nitrate. When nitrate reduction was established, we used this enrichment to inoculate serum bottles containing AGW, 10\% (weight:volume) autoclaved FRC sediment, $10 \mathrm{mM}$ acetate, $5 \mathrm{mM}$ nitrate, and increasing concentrations of mercury, provided as $\mathrm{HgCl}_{2}(53 \mathrm{nM}$ to $24 \mu \mathrm{M})$. Nitrate reduction was monitored for up to 220 days and the time it has taken for the enrichment to initiate nitrate reduction was used as an indication of mercury toxicity. Unexposed microcosms reduced the added nitrate in a period of 13 days. An inverse relationship was observed between $\mathrm{Hg}$ concentrations and onset of denitrification: nitrate reduction occurred on the $13^{\text {th }}$ day of incubation with no addition of $\mathrm{HgCl}_{2}$, but occurred on the $55^{\text {th }}$ day with $312 \mathrm{nM}$ of $\mathrm{HgCl}_{2}$. Above $1 \mu \mathrm{M}$ of 
$\mathrm{HgCl}_{2}$, nitrate reduction was not detected even on the $220^{\text {th }}$ day. These findings are being prepared for publication (Wiatrowski et al., in preparation).

Increasing $\mathrm{Hg}$ concentrations also decrease the number of dominating species selected in the enrichments as revealed by tRFLP patterns. The enrichment that was supplemented with $312 \mathrm{nM}$ of $\mathrm{HgCl}_{2}$, had a single tRFLP peak was most closely related to that of the alphaproteobacterium Bradyrhizobium sp., a known denitrifier, and a PCR fragment amplified from this enrichment by merA-specific primers, had $89 \%$ inferred sequence identity to MerA in Acinetobacter sp. suggesting the selection of $\mathrm{Hg}$ resistant bradyrhizobia in denitrifying enrichments. The role for this genus in the response to $\mathrm{Hg}$ in the FRC subsurface sediments was supported when $\mathrm{Hg}$ resistant denitrifying isolates from the enrichments were related to bradyrhizobia, one of which had a merA with $67 \%$ inferred sequence identity to MerA of the actinobacterium Nocardioides sp. Thus, denitrifying bradyrhizobia might be major players in $\mathrm{Hg}$ detoxification in the subsurface. These findings are being prepared for publication (Wang et al., in preparation). Together, these results suggest that (i) denitrification in subsurface sediments is highly sensitive to inhibition by $\mathrm{Hg}$; (ii) denitrification in the enrichments was restored upon selection and growth of $\mathrm{Hg}$ resistant bacteria; (iii) horizontally transferred merA genes might have contributed to this enrichment. While initial experiments with iron reducing enrichments did not provide reproducible results, later incubations were successful and the analyses and further examination of these incubation is currently progressing.

The reduction of $\mathrm{Hg}(\mathrm{II})$ by metal reducing anaerobic bacteria: One of the major findings of our project is that anaerobic metal reducing bacteria such as Shewanella oneidensis MR-1 and Geobacter spp. reduce $\mathrm{Hg}(\mathrm{II})$ to $\mathrm{Hg}(0)$ by a novel pathway that is not related to the mer-mediated resistance (Wiatrowski et al., 2006). These strains are of great interest for bioremediation in the subsurface due to their ability to reduce toxic metals and radionuclides. Additionally, these strains do not display $\mathrm{Hg}$ resistance typical of an organism with a mer operon. In the presence of $200 \mathrm{nM} \mathrm{Hg}$ (II), live cells of strain MR-1 grown aerobically reduced $83 \pm 6.3 \%$ of the $\mathrm{Hg}$ (II), whereas autoclaved cells reduced $21 \pm 0.9 \%$ in 24 hours. $\mathrm{Hg}$ (II) reduction by MR-1 also occurred with iron oxyhydroxide and fumarate as terminal electron acceptors. Reduction of $\mathrm{Hg}$ (II) showed a strong dependence on the presence of an electron donor and an electron acceptor, as incubation of cells in media which lacked either resulted in activity that is not significantly different from that of autoclaved cells ( $\mathrm{p}>0.01$ ). Unlike mer-mediated $\mathrm{Hg}$ (II) reduction, this activity is not inducible, as exposed cells and unexposed cells had a specific activity for reduction of $\mathrm{Hg}(\mathrm{II})$ of $3.14 \pm 0.25$ and $3.07 \pm 0.35 \mathrm{nmol} \mathrm{min}^{-1} \mathrm{mg}$ protein ${ }^{-1}$ respectively. Live and autoclaved cells of $G$. sulfurreducens PCA reduced $\mathrm{Hg}(\mathrm{II})$ with specific activities of $2.8 \pm 1.3 \mathrm{nmol} \mathrm{Hg}$ (II) $\mathrm{min}^{-1} \mathrm{mg}$ protein $^{-1}$ and $0.34 \pm 0.5 \mathrm{nmol} \mathrm{Hg}$ (II) $\mathrm{min}^{-1} \mathrm{mg}$ protein $^{-1}$, respectively. Live and autoclaved cells of strain G. metallireducens GS-15 had specific activities of $6.05 \pm 1.4 \mathrm{nmol} \mathrm{Hg}$ (II) $\min ^{-1} \mathrm{mg}$ protein ${ }^{-1}$ and $1.65 \pm 0.9 \mathrm{nmol} \mathrm{Hg}$ (II) $\min ^{-1} \mathrm{mg}$ protein ${ }^{-1}$, respectively. However, $\mathrm{Hg}(\mathrm{II})$ reduction is not universal among DMRB or anaerobes, as it was absent in Anaeromyxobacter dehalogenans strain 2CP-C, which can reduce iron, and the nitrate reducer Pseudomonas stutzeri OX1.

One of the most intriguing finding of these studies was based on the observation when grown using iron oxyhydroxide as a terminal electron acceptors, $\mathrm{Hg}$ (II) reduction 
only occurred if the strains were grown overnight prior to the addition of $\mathrm{Hg}$ (II) and reduction rates were 3 to 4 folds higher relative to rates that were observed using fumerate as an electron acceptor (Wiatrowski et al., 2006). These observations suggested the possibility that $\mathrm{Hg}$ (II) was reduced by ferrous iron (Fe[II]) that was the product of ferric iron $(\mathrm{Fe}[\mathrm{III}])$ reduction. We therefore investigated the redox transformation of $\mathrm{Hg}$ (II) in the presence of the $\mathrm{Fe}(\mathrm{II}) / \mathrm{Fe}$ (III) mixed valence iron oxide mineral magnetite. Kinetic and spectroscopic experiments were performed to elucidate reaction rates and mechanisms. The experimental data demonstrated that reaction of $\mathrm{Hg}$ (II) with magnetite results in the loss of $\mathrm{Hg}(\mathrm{II})$ and the formation of volatile $\mathrm{Hg}(0)$. Kinetic experiments showed that $\mathrm{Hg}(\mathrm{II})$ reduction occurred within minutes, with reaction rates increasing with increasing magnetite suspension density ( 0.05 to $0.2 \mathrm{~g} / \mathrm{L}$ ) and solution $\mathrm{pH}$ (4.8 to 6.7), and decreasing with increasing chloride concentration $\left(10^{-6}\right.$ to $\left.10^{-2} \mathrm{~mol} / \mathrm{L}\right)$. Mössbauer spectroscopic analysis of reacted magnetite samples revealed a decrease in $\mathrm{Fe}(\mathrm{II})$ content, corresponding the oxidation of $\mathrm{Fe}(\mathrm{II})$ to $\mathrm{Fe}(\mathrm{III})$ in the magnetite structure. X-ray photoelectron spectroscopy detected the presence of $\mathrm{Hg}(\mathrm{II})$ on magnetite surfaces, suggesting that adsorption is involved in the electron transfer process. These results suggest that $\mathrm{Hg}$ (II) reaction with solid-phase $\mathrm{Fe}(\mathrm{II})$ is a kinetically favorable pathway for $\mathrm{Hg}$ (II) reduction in magnetite-bearing environmental systems (Wiatrowski et al., 2009). Together, we have discovered two new pathways for the reduction of $\mathrm{Hg}$ (II) to $\mathrm{Hg}(0)$. The first is mediated by metal reducing bacteria, and the second is an abiotic reduction by $\mathbf{F e}(\mathbf{I I}) / \mathbf{F e}$ (III) bearing minerals. These processes may play a significant role in the transformation/mobilization of mercury in saturated subsurface sediments where metal reducing bacteria dominate and their activities affect the formation of iron minerals.

\section{References}

Krabbenhoft DP, Babiarz CL (1992). The role of groundwater transport in aquatic mercury cycling. Water Resoures Research 28: 3119-3128.

Schaefer JK, Yagi J, Reinfelder J, Cardona-Marek T, Ellickson K, Tel-Or S et al (2004). The role of the bacterial organomercury lyase (MerB) in controlling methylmercury accumulation in mercury contaminated natural waters. Environmental Science and Technology 34: 4304-4311.

Wang Y, Wiatrowski HA, John R, Kerkhof L, Young L, Barkay T. Community analysis and mercury resistant bacteria in denitrifying enrichments of subsurface sediments. In preparation.

Wiatrowski HA, Das S, Kukkadapu R, Ilton E, Barkay T, Yee Y (2009). Reduction of $\mathrm{Hg}(\mathrm{II})$ to $\mathrm{Hg}(0)$ by Magnetite. Envirnmental Science \& Technology 42: 5307-5313.

Wiatrowski HW, Ward PM, Young L, Barkay T (2006). Novel reduction of mercury(II) by mercury-sensitive dissimilatory metal reducing bacteria. Environmental Science and Technology 40: 6690-6696. 
Wiatrowski HA, John R, Wang Y, Barkay T. Mercury resistance and reduction in denitrifying enrichments of saturated sediments from the the Oak Ridge Field Research Ceneter. In preparation. 


\section{Published papers and conference presentations that have resulted of this project}

\section{Published papers and submitted manuscripts}

Ní Chadhain, S., J.K. Schaefer, S. Crane, G.J. Zylstra, and T. Barkay. 2006. Analysis of mercuric reductase $(\operatorname{mer} A)$ gene diversity in an anaerobic mercury-contaminated sediment enrichment. Environ. Microbiol. 8:1746-1752

Wiatrowski, H.A., P.M. Ward, and T. Barkay. 2006. Novel reduction of mercury(II) by mercury-sensitive dissimilatory metal reducing bacteria. Env. Sci. Technol. 40:66906696

Golding, G.R., C. A. Kelly, R. Sparling, P. C. Loewen, and T. Barkay. 2007. Evaluation of mercury toxicity as a predictor of mercury bioavailability. Env. Sci. \& Technol. 41:5685-5692

Wiatrowski, H.A. S. Das, R. Kukkadapu, E. Ilton, T. Barkay, and N. Yee. 2009. Reduction of $\mathrm{Hg}(\mathrm{II})$ to $\mathrm{Hg}(0)$ by Magnetite. Env. Sci \& Technol. 42:5307-5313

\section{Conference presentations}

Barkay T, Schaefer, J, Poulain, A. and, Amyot M. Microbial transformations in the mercury geochemical cycle. $15^{\text {th }}$ Goldschmidt Conference. Moscow, Idaho, May 20-25, 2005. Invited talk

Wiatrowski, H. A., and T. Barkay. A novel mechanism for reduction of mercury (II) by Shewanella oneidensis MR-1. 105 ${ }^{\text {th }}$ Annu. Meet. Am. Soc. Microbiol. Atlanta, June 5-9, 2005.

Schaefer, J., and T. Barkay. Diversity of mercuric reductase (MerA) genes and transcripts in mercury contaminated waters. $105^{\text {th }}$ Annu. Meet. Am. Soc. Microbiol. Atlanta, June $5-9,2005$.

Wiatrowski, H., and $\mathrm{T}$. Barkay. Reduction of $\mathrm{Hg}(\mathrm{II})$ to $\mathrm{Hg}(0)$ by dissimilatory metal reducing bacteria. $8^{\text {th }}$ International Conference on Mercury as a Global Pollutant. Madison, WI, Aug. 11-Aug 16, 2006.

Øregaard, G., J.R. de Lipthay, T. Barkay, and S.J. Sørensen. High diversity of bacterial mercuric reductase genes from surface and sub-surface soil. $11^{\text {th }}$ International Symposium on Microbial Ecology. Viena, Austria, Aug. 20-25, 2006

Wang, Y., H.A. Wiatrowski, R. John, P. Lu-Irving, L. Young, L. Kerkhof, and T. Barkay. Impact of mercury on denitrifying microbial communities in subsurface sediments. $109^{\text {th }}$ Annu. Meet. Am. Soc. Microbiol. Philadelphia, May 17 - 21, 2009 
Ziogaite, B., B. Smith, A. Chatziefthimiou, T. Barkay, and J. Coombs. Isolation and Microarray Analysis of Cryptic Plasmids from Metal Resistant Bacteria of the Deep Terrestrial Subsurface. $109^{\text {th }}$ Annu. Meet. Am. Soc. Microbiol. Philadelphia, May $17-$ 21,2009

Chatziefthimiou, A.D. A.L. Isola, and T. Barkay. Mercury Contamination and its Effects on Phylogenetic and Functional Diversity of Soil $\mathrm{Hg}^{\mathrm{R}}$ Bacteria. $109^{\text {th }}$ Annu. Meet. Am. Soc. Microbiol. Philadelphia, May 17 - 21, 2009 